University of Chicago Law School

Chicago Unbound

Journal Articles

Faculty Scholarship

1984

\title{
Labor Markets and Labor Law Compared with Capital Markets and Corporate Law
}

Daniel R. Fischel

Follow this and additional works at: https://chicagounbound.uchicago.edu/journal_articles

Part of the Law Commons

\section{Recommended Citation}

Daniel R. Fischel, "Labor Markets and Labor Law Compared with Capital Markets and Corporate Law," 51 University of Chicago Law Review 1061 (1984).

This Article is brought to you for free and open access by the Faculty Scholarship at Chicago Unbound. It has been accepted for inclusion in Journal Articles by an authorized administrator of Chicago Unbound. For more information, please contact unbound@law.uchicago.edu. 


\title{
Labor Markets and Labor Law Compared with Capital Markets and Corporate Law
}

\author{
Daniel R. Fischel†
}

This essay sketches some differences between labor and capital markets and between labor and corporate law. This is a natural comparison because labor and capital are two different factors of production in all firms. Despite the obvious appeal of this comparison, it has largely been ignored in the existing literature.

Two assumptions seem to me-a nonspecialist in the field-to underlie much of contemporary labor law: (1) employers, left to their own devices, will oppress workers; and (2) this problem of worker exploitation is best handled by a federal labor policy administered by an administrative agency. Corporate law, by contrast, makes the opposite assumptions. Firms are for the most part free to adopt whatever institutional arrangement they choose; and state, not federal, law controls. What accounts for these fundamental differences?

While some differences between labor and capital markets do exist, I argue that they do not justify the differences between labor and corporate law. In particular, the tendency of firms to reach efficient contractual arrangements, and to economize on transaction costs by choosing to be governed by a particular set of standard-form contractual terms embodied in state law, is relevant to both labor and capital markets.

In Part I, I discuss the incentives of firms and workers (or investors) to enter into contracts that work to the mutual benefit of both; Part II touches on the probable superiority of state over federal regulation of labor (or investor) relations. In Part III, I focus on several controversial aspects of labor-management relations-the role of unions, contracts terminable at will, the right to strike, and labor constituent directors-as examples of the principles developed in the first two sections. Finally, Part IV discusses some distributional arguments that might be used to justify differ-

$\dagger$ Professor of Law, University of Chicago. The author gratefully acknowledges the extremely valuable comments of Gary Becker, Dennis Carlton, Frank Easterbrook, Richard Epstein, Victor Goldberg, William Landes, John Langbein, Edward Lazear, Geoffrey Miller, Richard Posner, Steven Shavell, and Cass Sunstein. 
ences between labor and corporate law.

\section{The Incentive to Enter into Mutually Beneficial Contracts}

Imagine an entrepreneur who wants to undertake a new venture and who thus needs to raise capital. Because potential investors always have the opportunity to invest elsewhere, the entrepreneur will have to provide them with credible information about the venture in order to demonstrate its superiority over alternative investments. Potential investors will also be concerned about use of the proceeds by the entrepreneur once the funds are invested. At the extreme, potential investors are concerned that the entrepreneur will simply pocket all the proceeds and leave investors with nothing. Less extreme agency problems range from self-dealing of various sorts to a simple lack of hard work by the entrepreneur. The greater the investors' concerns over these agency problems, the less they are willing to pay for a given percentage of the income generated by the firm's assets. In order to convince investors to pay more, the entrepreneur has to enter into institutional arrangements that limit his discretion to further his own interests at the expense of investors. ${ }^{1}$

Though oversimplified and abstract, this discussion fairly describes the actual operation of capital markets. Firms that wish to raise capital from lenders enter into detailed contractual arrangements describing the nature of the project and limiting the ability of the borrower to behave in ways that are detrimental to the lender. ${ }^{2}$ Similarly, firms employ a variety of monitors and informational intermediaries such as independent accountants, investment bankers, and independent directors in order to convince suppliers of capital (lenders and shareholders) that the project is worthwhile and that agency problems will be kept to a minimum. ${ }^{3}$

It is worth emphasizing that these voluntary concessions by those who want to raise capital are motivated purely by self-interest. All firms (entrepreneurs) want to minimize their cost of capital, just as they want to minimize the cost of all other factors of

1 For a fuller discussion of the agency-cost problem, see generally Jensen \& Meckling, Theory of the Firm: Managerial Behavior, Agency Costs and Ownership Structure, $3 \mathrm{~J}$. Fin. ECon. 305 (1976).

${ }^{2}$ For a discussion and description of the arrangements between firms and bondholders, see Smith \& Warner, On Financial Contracting: An Analysis of Bond Covenants, 7 J. Frn. EcoN. 117, 125-46 (1979).

s See Easterbrook \& Fischel, Mandatory Disclosure and the Protection of Investors, 70 VA. L. REv. 669, 675 (1984). 
production. Because it is the firm (the entrepreneur) that bears the cost of institutional arrangements that operate to the detriment of investors, the firm is able to lower its cost of capital by adopting institutional arrangements that minimize the resources wasted by investors in determining the suitability of investments and in monitoring the behavior of the firm's agents. Society as a whole also suffers when inefficient governance structures are adopted because fewer goods and services are produced. But investors do not suffer: they are indifferent between investing at a lower price in a firm with an inefficient institutional arrangement and investing at a higher price in a firm where they are better protected.*

This important insight-that it is in the interest of the firm (entrepreneur) to adopt efficient contractual arrangements because the firm pays for inefficiencies through a higher cost of capital-is implicitly recognized by corporate law. Under modern enabling statutes, firms are for the most part free to adopt whatever structures they choose. State corporate statutes provide a set of standard-form terms, but firms are generally free to alter these terms in their charters or by-laws. ${ }^{5}$ The judicial function is largely confined to enforcing the agreement (sometimes implicit) between the parties. The federal securities laws impose upon firms mandatory obligations that cannot be varied by agreement, but their focus is on disclosure; in the main, they do not restrict firms' ability to adopt whatever institutional arrangements they wish, so long as the arrangements are disclosed. To be sure, corporate law has attracted many critics who have consistently decried the absence of regulatory constraints on firm structure. But these critics have been utterly uninfluential in the development of the law; and, for the reasons stated above, this lack of influence has been all to the good. ${ }^{6}$

Labor law is strikingly different. The assumption dominant in corporate law-that firms have incentives to adopt contractual provisions that maximize investors' wealth-is completely alien to labor law. Rather, labor law generally assumes that unless firms are subjected to direct regulation, they will adopt governance mecha-

- Once an investment has been made, of course, the investor prefers that the firm adopt the most efficient institutional arrangement possible. If firms do so, investors' wealth is maximized. In this sense, all investors prefer efficient contractual arrangements.

see, e.g., Del. CoDs ANN. tit. 8, \& 223 (1974) (providing standard procedures for filling directorship vacancies but allowing those procedures to be altered by the firm's certificate of incorporation or by-laws).

- For a fuller discussion, see Fischel, The Corporate Governance Movement, 35 VaND. L. REv. 1259 (1982). 
nisms that oppress labor. Firms, for example, are forbidden to create company unions, to require workers to forego union affiliation as a condition of employment, to have an announced policy of firing all employees who engage in concerted activity, or to disseminate certain types of truthful information during unionization campaigns. The freedom of firms, under corporate law, to enter into whatever contractual arrangements they choose is generally absent in labor law. ${ }^{7}$

This may appear to be something of an overstatement. Although labor law does restrict freedom of contract in several respects, in other respects it does not. Unions and firms, for example, have a "duty to bargain in good faith" on "mandatory" subjects of bargaining, although they are not compelled to agree on any particular term. But what does it mean to have such a duty? The Coase Theorem ${ }^{8}$ predicts that parties will reach mutually advantageous agreements regardless of the legal rule under which they bargain. The duty to bargain in good faith therefore appears to be superfluous unless it implicitly coerces employers to agree to particular substantive terms. ${ }^{\circ}$ Thus, labor law contains direct and indirect regulation of contract terms that is absent in corporate law.

Another reason why labor law and corporate law may be more similar than the preceding discussion suggests is the relatively small percentage of workers who are unionized. Only about twenty percent of the workforce is unionized, and labor law thus cannot be equated with the law governing labor unions. But the implicit rejection of the desirability of flexible contractual arrangements that is embodied in federal labor law extends to many other facets of employer-employee relations. Thus, firms must, under federal law, pay workers a minimum wage, structure their pension plans in particular ways, provide certain safety benefits, and avoid a policy of mandatory retirement before the age of seventy. Moreover, some aspects of state regulation of employer-employee relations-such

7 For a useful general discussion of the principal features of American labor law, see Posner, Some Economics of Labor Law, 51 U. CH. L. REv. 988, 991-99 (1984).

B See Coase, The Problem of Social Cost, 3 J.L. \& Econ. 1 (1960).

- An alternative explanation is that the duty to bargain in good faith is an attempt to discourage strategic behavior by either of the parties. In relational contracts where strategic behavior is common, however, either attempts to negotiate or refusals to negotiate may indicate strategic behavior. See Goetz \& Scott, Principles of Relational Contracts, 67 VA. L. Rev. 1089, 1100-01 (1981); cf. Muris, Opportunistic Behavior and the Law of Contracts, 65 MinN. L. Rev. 521 (1981) (discussing strategic behavior during the course of contracts). Moreover, both unions and firms have equal ability to engage in strategic behavior. In practice, however, the legal duty to bargain has been imposed only on employers. This casts doubt on the avoidance-of-strategic-behavior explanation. 
as the frequent abrogation of the contract terminable at will ${ }^{10}$ - seems to be characterized by the same assumptions that underlie federal regulation of the employer-employee relationship.

What accounts for the fundamental distinction between the regulation of labor and capital markets? Labor and capital are two different inputs to the production processes of particular firms. If a self-interested firm has incentives to adopt the contractual arrangements that shareholders prefer, why doesn't the identical firm have the same incentives with respect to workers? Initially, it would seem that similar tendencies would be at work. If workers (for simplicity I am ignoring differences among workers) prefer compensation to take the form of fringe benefits or safer working conditions rather than higher wages, the firm has a strong incentive to accomodate their preferences. If workers as a class prefer unions or some other type of collective representative to individual bargaining, firms will contract with unions voluntarily; indeed, firms would compete for labor by advertising their willingness to deal with unions in the same manner that firms compete for capital by advertising their willingness to be subject to scrutiny by independent third-party auditors. Firms would voluntarily enter into both types of arrangements in order to minimize the cost of a factor of production. Nothing turns on whether the firm is seeking to minimize its cost of capital or its cost of labor.

Despite the obvious similarities between the operation of capital and labor markets, some possible differences between the two might be thought to justify the greater bias toward regulation in labor markets. The three most important differences are that capital markets are closer to the ideal of perfect competition than labor markets; that possibilities of firm-specific investments exist in labor markets that do not exist in capital markets; and that participants in labor markets have less ability to diversify risk. The implications of these differences, however, are ambiguous.

Investors in capital markets are protected by the virtually infinite number of investment substitutes. Firms compete for investment dollars, and investors who are dissatisfied with a particular investment can sell it without difficulty. ${ }^{11}$ Nor is it necessary for each investor to be aware of the characteristics of particular firms.

10 For a stimulating discussion of the common law rule and its recent decline, see Epstein, In Defense of the Contract at Will, 51 U. CHI. L. REv. 947 (1984).

12 Even under the implausible assumption that all firms collude, investors can put their money in the bank, buy real estate, purchase government debt instruments, and so forth. Moreover, this option (exiting from the market) is close to costless. 
So long as market prices of securities reflect the relevant characteristics of particular firms-and the evidence indicates that they do-it is very hard for an investor to make what is ex ante a bad deal. By accepting the market price, investors are protected. ${ }^{12}$

Labor markets exhibit far different characteristics. Apart from competition for labor among firms, fewer substitutes exist for labor opportunities. Being self-employed, in other words, is for workers a less efficient substitute than placing money in the bank is for investors. Moreover, because of the difficulties associated with relocating, the exit option is much more costly for workers than for investors. Finally, labor is a more heterogeneous good than capital; as a result, accepting the market wage of a particular firm without search might be a less rational strategy for workers than accepting the market price of a security is for investors.

One possible effect of these differences between labor and capital markets is that firms might be able to offer a different and inferior package, particularly lower wages, than would prevail under perfect competition. But the magnitude of this effect might also be very small. It is not necessary that there be an infinite number of competitors for a market to behave competitively; indeed, industries with a few large firms can and often do exhibit the characteristics of a competitive industry. ${ }^{13}$ Nor is it necessary that all participants in a particular market be well-informed for the market to behave competitively. So long as there are a sufficient number of informed shoppers, firms will not be able to offer inferior products (conditions of employment) or charge supracompetitive prices (pay below-market wages). ${ }^{14}$ And if employment terms are competitively set, the uninformed will tend (at least if price discrimination is rare) to be protected.

Ultimately, of course, questions about the relative competi-

12 See Fischel, Use of Modern Finance Theory in Securities Fraud Cases Involving Actively Traded Securities, 38 Bus. Law. 1, 12-13 (1982).

1s See, e.g., Kwoka, The Effect of Market Share Distribution on Industry Performance, 61 REv. Econ. \& STATISTICs 101 (1979); Ravenscraft, Structure-Profit Relationships at the Line of Business and Industry Level, 65 REv. Econ. \& Statistics 22 (1983). Of course, this does not negate the possibility that an occasional employer may have monopsony power because it is the only firm in an industry or is geographically isolated. Such situations are, however, relatively rare. Moreover, exit by workers and potential entry by firms into low-wage areas are at least partial checks on these rare cases of monopsony power.

14 See Schwartz \& Wilde, Intervening in Markets on the Basis of Imperfect Information: A Legal and Economic Analysis, 127 U. PA. L. Rev. 630, 637-39 (1979); see also Schwartz \& Wilde, Competitive Equilibria in Markets for Heterogeneous Goods Under Imperfect Information: A Theoretical Analysis with Policy Implications, 13 BkLl J. EcoN. 181, 192 (1982). 
tiveness of labor markets are empirical. While generalizations are difficult, a substantial body of evidence suggests that labor markets are surprisingly competitive even in situations where intuition might suggest otherwise. ${ }^{15}$ The competitive nature of labor markets indicates that labor markets might differ less from capital markets than the differences between labor and corporate law would suggest.

The possibility of firm-specific investments of human capital in labor markets raises a somewhat different problem. It suggests that although labor markets may be competitive at the time of the original negotiation, they may not remain competitive after one of the parties becomes dependent on the other (or at the very least faces the cost of relocation). At the extreme, a firm could hire a worker and then reduce his wage to a level just above the worker's opportunity wage minus the worker's cost of relocation. Workers in competitive labor markets realize this possibility, however, and demand compensation ex ante. In order to allay workers' rational concerns and thereby reduce the amount of compensation that must be paid, firms have incentives to adopt governance mechanisms that reduce the probability of opportunistic behavior by the firm ex post. ${ }^{16}$ One possibility is for firms to strengthen the "voice" alternative for workers: grievance-resolution mechanisms of various kinds decrease the ability of firms to engage in opportunistic behavior at workers' expense.

The third major difference between capital and labor markets is the relative inability of participants in labor markets to diversify risk. Human capital, unlike capital investments in particular firms, is notoriously difficult to diversify. But again, the implications of this point for the regulation of labor markets are obscure. In competitive labor markets, inefficient risk-bearing is of little consequence for workers with no firm-specific investment of human capital. Apart from the costs of relocating, this class of workers has the ability to shift its labor to other firms if one particular firm suffers an economic downturn. Relative inability to bear risk is relevant, however, for risk-averse workers whose firm-specific invest-

is See, e.g., Roback, Southern Labor Law in the Jim Crow Era: Exploitative or Competitive?, 51 U. ChI. L. Rgv. 1161 (1984); see also Robert Higgs, Competition and CokrCLON: Blacks in THE American Economy, 1865-1914 (1977).

10 It is important to recognize the reciprocal nature of this problem. Firms can have specific investments in workers just as workers can have specific investments in firms. Thus, there is a need to develop governance structures that minimize opportunistic behavior by workers. Pensions with long vesting periods provide an example of a contractual mechanism that does this. 
ments of human capital constitute a large percentage of their wealth. These workers will demand compensation for having to bear risk; conversely, firms will attempt to design contractual arrangements-providing such risk-shifting devices ${ }^{17}$ as long-term contracts or severance-pay provisions-in order to minimize the risk borne by workers. In short, we should observe different governance mechanisms in labor markets than in capital markets, but there is no reason to believe that workers will be systematically worse off than investors.

It is worth emphasizing that I am not claiming that workers will never enter into bargains that do not work out well ex post; I am not even claiming that all workers will make prudent bargains as judged ex ante. Investors do not always make perfect bargains either. My point is that it is extremely unlikely that either workers or investors will be systematically exploited in any meaningful sense. The interest of the firm in minimizing the cost of all inputs in the production process will cause it to adopt the contractual mechanisms that best allay workers' and investors' rational concerns.

\section{State versus Federal Regulation}

Thus far I have implicitly assumed that the costs of reaching and enforcing optimal contracts are negligible. This assumption is, of course, false since the costs of negotiating and enforcing contracts are clearly positive. Legal rules can reduce these costs, however, by providing a standard contract that governs contractual relationships when the parties do not manifest an intent to the contrary.

Initially, it may appear that managers would choose to be governed by legal rules that give them maximum discretion. But this is incorrect. Managers would not want such rules any more than they want express contractual provisions that provide maximum discretion. The problem in both cases is that managers would have to pay for this discretion in the form of ex ante compensation.

This point is implicitly recognized by corporate law. ${ }^{18}$ In deciding where to incorporate, managers have a choice of being governed by the laws of any of fifty states. Poor choices lead to lower share prices (higher cost of capital) or to exit by investors to firms

${ }^{27}$ See Kraakman, Corporate Liability Strategies and the Costs of Legal Controls, 93 YALE L.J. 857, 865 (1984).

${ }^{18}$ See Ralph Winter, Government and the Corporation 7-11 (1978). 
governed by other states' laws. The ability of managers to exploit investors by choosing to be governed by a particular state's laws is thus extremely limited. Conversely, competition among states allows managers to choose among a large number of different standard contracts. This choice is almost certainly beneficial to investors as a class because there is no reason to believe that one standard contract will be optimal for every firm. The case in favor of competition among states is particularly strong since there are no obvious externalities across states or dangers of interstate exploitation. ${ }^{19}$

The concept of a competition among states, however, is alien to labor law (with the important exception of right-to-work laws). Labor law is primarily federal law, administered by a federal agency and the federal courts; inconsistent state laws are preempted. The underlying assumption of this aspect of labor law-that workers are victimized rather than benefited by firms' having a choice of several standard contracts-is again in fundamental oppostion to the assumption underlying corporate law.

But why should depriving a firm of any choice in the rules by which it will be governed make its workers better off when investors of the same firm are made worse off? At first blush, workers appear to benefit from competition among jurisdictions in exactly the same way that investors do. Assume, for example, that unions enhance productivity in some firms but not others. Those firms for whom unions create benefits would locate in states with laws that facilitate unionization while the reverse would be true for other kinds of firms. It would be irrational for a firm that could increase productivity by allowing unionization to locate in a state that made this more difficult. Poor choices would be penalized in the same manner as in capital markets. Firms that made such choices would have to pay workers higher wages or other compensation to keep them from seeking employment elsewhere.

For this penalty to work perfectly, exit would have to be as costless in labor markets as it is in capital markets; but this, of course, is not the case. Nevertheless, as several studies have shown,

10 This analysis ignores the possibility that states might compete through laws that facilitate monopolization of labor markets. There could be an externality if supracompetitive wages were paid to workers within a state and if the costs were partially borne by consumers and investors in other states. The solution to this problem, however, would not be national labor laws, but rather application of the antitrust laws in order to prevent exporting the costs of monopoly. See Easterbrook, Antitrust and the Economics of Federalism, 26 J.L. \& EcoN. 23, 45 (1983). 
mobility in labor markets should not be underestimated..$^{20}$ Workers commonly move from state to state, even country to country, in pursuit of better opportunities. At the very least, the ability of workers to move from state to state constrains the ability of any one state to enact laws that systematically operate to the detriment of workers. Even if exit by workers were extremely costly, competition among states would still protect workers. If, for example, a firm established itself in a state that prohibited unions even though unions (by assumption) would increase productivity, the firm (owners of other factors of production as well as the workers) would suffer. ${ }^{21}$

Some might argue that competition among states in labor law will increase the flow of migration by firms from states that are pro-labor to states that are not. Why should firms pay $X$ for labor in state $A$ when they can relocate in state $B$ and pay one-half $X$ ? And what will happen to workers in state $A$ who are displaced? They must bear the costs of moving to state $B$ and, when they get there, they will only make fifty percent of what they made before.

The relevant inquiry, however, is commonly overlooked. Why are workers in state $B$ willing to work for half of what they could make in state $A$ ? Two possibilities suggest themselves. The first is that workers in state $B$ value the climate or other attributes of state $B$ so much that they are willing to accept lower wages rather than relocate in state $A$. Workers in this situation would not leave state $B$ en masse for the same reasons that not all lawyers want to practice in New York City. A second possible explanation for workers' failure to move from state $B$ to state $A$ is that no employment opportunities exist in state $A$ because wages are artificially high due to monopoly; in this event, state $B$ acts as a cartel breaker. A true national labor law (which, because of right-to-work laws, does not currently exist) would prevent competition among states and thus have the effect of enforcing a cartel.

\section{SOME EXamples}

One of the main themes of the preceding two sections is that

\footnotetext{
so For a summary of the evidence on this point, see Greenwood, Research on Internal Migration in the United States: A Survey, 13 J. Econ. Literature 397, 413-14 (1975); see also R. EHRENBERg \& R. SMITH, MODERN LABOR Economics 276-88 (1982).

21 Alternatively, if productivity is unaffected by unions, but the probability that firms will not honor their contracts is increased because of the absence of the union as a monitor, firms' cost of labor will increase. Firms obviously have strong incentives to maximize the size of the pie and minimize their cost of labor regardless of the cost of the exit option.
} 
there is no such thing as a contractual provision or state law that can unambiguously be called "pro" or "anti" capital or labor. Because of the effect on the firm's cost of capital, an entrepreneur would not view a contractual provision or state law that allowed him unlimited discretion as "pro-management." Similarly, because of the foregone benefits from efficient division of labor and risk bearing, shareholders would not view a contractual provision or state law that gave them exclusive control over decisionmaking as "pro-investor." Exactly the same is true in the labor context: things are not always as they first appear. In this section, I illustrate this point with several examples.

\section{A. The Role of Unions}

Most economists are hostile to unions because they view them as attempts by workers to act in concert for the purpose of charging monopoly prices for their labor. ${ }^{22}$ Only the labor exemption to the antitrust laws, it is widely believed, enables workers to act collectively without violating the antitrust laws. Under this standard monopoly view, unions reduce the value of the firm. Equating collective action with monopoly, however, may be incorrect. It is possible that collective action by workers is consistent with maximizing the value of the firm.

Pervasive monitoring problems in the web of agency relationships that is the publicly held corporation have led to a variety of collective responses. It would be highly inefficient, for example, for individual shareholders to negotiate with a corporation's managers, monitor self-dealing, evaluate quality of performance, and so forth. Massive free-rider problems would doom any such attempt. Individual shareholders would benefit according to the size of their holdings, rather than according to their monitoring efforts. These free-rider problems are minimized by having a board of directors that acts on behalf of all shareholders. Similarly, bondholders of a corporation realize that the directors might take certain actions adverse to their interests, such as adopting an overly risky investment strategy or paying out too many assets. An individual bondholder rarely has the incentive to monitor these actions. The development of the indenture trustee, who negotiates and monitors on behalf of individual bondholders, is another partial solution to the free-rider problem.

23 For a forceful statement of this view, see Posner, supra note 7. A minority of economists disagree. See, e.g., R. Frezman \& J. Mkdofk, What Do Unions Do? 19 (1984). 
Free-rider problems plague workers in the same manner that they plague shareholders and bondholders. Assume, for example, that a firm promises its workers a pension upon retirement and establishes a separate fund for this purpose. The probability that the promise will be kept depends on the level of contributions to the fund and the way the proceeds are invested. But no individual worker has the incentive to monitor the fund. Worker safety is another example where free-rider problems are likely to be serious. Unions, like boards of directors and indenture trustees, appear to be an attempt to minimize this free-rider problem. Since no one is concerned about the need for a shareholders' or bondholders' exemption from the antitrust laws, why is labor different?

If there is a difference, it is that a collective response to the free-rider problem creates a greater risk of monopolization in the labor area since there are better substitutes for capital than for labor. Because of the availability of alternative sources of funds (including retained earnings), it is inconceivable, for example, that an indenture trustee could negotiate a monopoly return for capital. Unions have a somewhat greater ability to obtain monopoly wages, particularly if they have the ability to prevent the hiring of substitutes by force or intimidation. But this ability is severely constrained by competition in the product market. Monopoly wages are most likely to persist where competition in the product market is limited because of either a cartel or government regulation. In other words, imperfect competition in product markets creates the possibility of monopoly rents; unions may simply appropriate these rents from other factors of production. When barriers to entry in the product market disappear, however, so do monopoly wages. The recent deregulation of the airline industry, and the simultaneous enormous "give backs" by affected unions, is a particularly good example of this phenomenon. Conversely, however, the survival of unions in competitive industries casts into question the pure-monopoly explanation of unions. ${ }^{23}$

One method of distinguishing between the union as an attempted solution to the free-rider problem and the union as monopoly is to analyze the behavior of firms. If unions were solely a rational response to the free-rider problem, firms would voluntarily deal with them. Just as firms voluntarily have their financial state-

${ }^{23}$ If unions could cartelize an entire industry, unionization could be consistent with competitive product markets. Such cartels would be unstable, however, because individual firms could refuse to deal with the union and thus increase their market share. New entry and foreign competition also threaten such attempted industry-wide cartels. 
ments audited in order to reduce their cost of capital, so would firms voluntarily deal with unions in order to reduce their cost of labor. The firm that promised its workers a pension in the above example wants this promise to be credible. Otherwise, workers will value it at zero and demand some other form of compensation. Furthermore, the size of the pie might be smaller if the pension was initiated primarily to induce workers to make firm-specific investments of human capital. If the firm deals with a union, by hypothesis, the promise is more credible and the cost of labor goes down.

Perhaps some firms do deal with unions voluntarily; company unions, for example, may have been an early evolutionary response to the free-rider problem. But casual empiricism suggests that firms frequently oppose organization drives by unions. This opposition creates substantial doubt about the hypothesis that (at least under the current regulatory climate where unionization means being regulated by the National Labor Relations Board and federal labor laws) minimizing the free-rider problem is the dominant explanation for the existence of unions. ${ }^{24}$ Attempted appropriation of monopoly rents created by imperfections in the product market is a likely alternative explanation. Under this view, the allocative losses from unions are the resources wasted in fighting over the monopoly rents that result from imperfections in the product market.

Considerable anecdotal evidence suggests, however, that the social loss caused by unions is greater than the resources expended in division of monopoly rents. Unions are commonly observed opposing technological change and plant relocations and insisting on wasteful featherbedding. Union involvement in these decisions seems inefficient because union leaders lack business expertise. Intuitively, they seem more qualified to decide whether an employee grievance is justified than whether future demand for a product will be sufficient to keep open a plant. To the extent that this kind of anecdotal evidence about unions is reliable, the allocative loss from unionization can be assumed to be greater than the rent-seeking explanation would imply.

The prohibition in labor law of direct payments by employers to unions is particularly hard to understand in this context. The

26 Another piece of evidence that casts doubt on the efficiency theory of unions is industry-wide bargaining. If unions increased efficiency, one would predict bargaining at the firm rather than the industry level. Industry-wide bargaining suggests an attempt to monopolize the labor market. 
Coase Theorem suggests that the bargaining process between workers and employers should create a tendency away from inefficient methods of production. The statutory bar on payments to unions inhibits this process, however, because the employer cannot buy out the collective rights of employees. The result is a smaller pie, which is detrimental to workers as a class as well as to other factors of production.

\section{B. The Right to Strike and Contracts Terminable at Will}

The ability to strike is often asserted to be one of the fundamental rights of workers; the right to fire employees at will is alleged to be of equal importance to employers. Both involve disruptions of ongoing relationships.

There is some truth to these perceptions, but they are also misleading when they abstract from the reciprocal benefit created by efficient contractual terms. The ability to strike is presumably valuable to employees because of the increased likelihood that firms will honor their contractual commitments. But firms are correspondingly interested in making credible promises to decrease their cost of labor. Allowing workers the right to strike may make all parties better off. Similarly, the contract at will can benefit employees as well as employers. Accepting contracts at will may be a signaling device whereby qualified, hard-working employees can distinguish themselves from their less able and less industrious counterparts and thereby obtain higher wages. Alternatively, contracts at will may economize on transaction costs in situations where workers have made no firm-specific investments and thus are not significantly injured by discharge. Finally, contracts terminable at will may be beneficial when future economic conditions are uncertain. If employers realize that they can reduce the size of the work force in the event of an economic downturn, they will be more willing to hire in the first place.

It is also possible to imagine situations where both parties would be worse off if workers have the right to strike or firms have the ability to discharge at will. The right to strike may be an inefficient method of enforcing contract terms. Because strikes involve reductions in output, they may be inferior to reliance on innovative reward and penalty provisions enforced by ordinary contract law. Moreover, enforcing contract terms is not the only possible use of the right to strike. Because a strike can impose losses on a firm (other factors of production), workers can use the right to strike opportunistically. In other words, the right to strike can be employed to coerce the firm into providing benefits to workers not 
provided in the initial agreement. Firms recognize this possibility and are thus willing to pay less for labor ex ante. Workers, therefore, might rationally forego the right to strike in return for higher compensation. ${ }^{25}$

Contracts terminable at will pose the same issues. Suppose a firm wants to induce workers to make a firm-specific investment. After making the investment, the workers will be more valuable to that particular firm than to any other. Rational workers realize, however, that they are at risk of opportunistic behavior by firms. The firm can threaten the workers with termination if they do not accept a reduction in their compensation to some amount above their next best opportunity. This prospect, of course, reduces the willingness of workers to make firm-specific investments in the first place. But if the firm's profitability will be maximized by such investments, firms will take measures ex ante to induce them. Employment contracts that are not terminable at will and informal grievance-resolution machinery are two measures that firms might employ to reduce the risk of opportunistic behavior.

\section{Labor Constituent Directors}

Some have advocated labor representation on boards of directors. ${ }^{28}$ Workers, presumably, are the intended beneficiaries of such proposals, but it is far from clear that they would benefit. For several reasons, labor representatives lack the appropriate incentives to maximize the value of the firm. Workers are residual claimants in only the most limited sense. Most of the gains and losses from a firm's investment decisions are borne by its stockholders, not by its workers. Thus, workers do not have the correct incentives to exercise discretion in choosing among investment projects. ${ }^{27}$ Nor would it make sense for workers to become residual claimants. Because their horizon is limited by their working life, their investment decisions will be skewed in favor of those with a quick payoff even if they have a negative net present value. ${ }^{28}$ Finally, workers have

${ }^{25}$ It is interesting that investors in publicly held firms cannot withdraw their capital if they are dissatisfied. This suggests that workers, too, might rationally forego the right to withdraw their labor, penalty-free, from the firm.

2* In the United States, labor is generally not represented on boards of directors. See Summers, Worker Participation in the U.S. and West Germany: A Comparative Study from an American Perspective, 28 AM. J. CoMp. L. 367, 370-71 (1980).

${ }^{27}$ For a fuller discussion of this point, see Easterbrook \& Fischel, Voting in Corporate Law, 26 J.L. \& EcoN. 395, 403-06 (1983).

"8 For a discussion of the "horizon effect," see Jensen \& Meckling, Rights and Production Functions: An Application to Labor-managed Firms and Codetermination, 52 J. Bus. 
poor incentives to manage a firm because they frequently have little at stake. Investors in a firm risk the value of their investment; workers risk the value of their firm-specific investment, which in many cases will be small or nonexistent. Because workers have less at stake, they lack proper incentives to maximize the value of the firm. ${ }^{28}$

In light of these considerations, it is not surprising that labor directors are common only where compelled by government regulation, as in Germany. Workers prefer to be able to delegate firms' decisionmaking to those who have better incentives than they do in exchange for a slice of the larger pie. Once again, neither workers nor other parties contracting with the firm benefit from inefficient contractual arrangements.

\section{Distributional Arguments}

Some proponents of labor law might concede some or all of the above and yet still favor the status quo (or even greater federal intervention) on distributional grounds: such measures might be thought desirable in order to guarantee higher wages to workers. Several responses can be made. First, the implicit assumption of this argument-that wealth should be redistributed from "wealthy" firms to "poor" workers-is highly misleading. A corporation is a legal fiction and hence has no wealth. Shareholders have wealth but may well be, and often are, themselves workers who are the beneficial owners of shares held by a pension fund or other financial intermediary. Thus, the resulting redistribution may simply be from one nonwealthy group to another or, at the extreme, from workers to themselves. Second, the higher wages may be a result of monopoly, which entails reduced output and a smaller pie: fewer workers can be employed, consumers must pay higher prices, and so forth. Unless some argument exists to explain why those who benefit from monopoly are somehow more worthy than others who must bear the (greater) costs, the distributional argument in favor of monopoly seems particularly weak.

Another distributional argument in support of intervention in labor markets is that market outcomes are the product of existing preferences and the existing distribution of wealth and are thus

\footnotetext{
$469,482-84$ (1979).

29 See Williamson, Corporate Governance, 93 YaLe L.J. 1197, 1206 (1984); cf. Williamson, Transaction-Cost Economics: The Governance of Contractual Relations, 22 J.L. \& EcoN. 233, 255 (1979) (arguing that no special governance structures are needed to protect workers who have not made firm-specific investments).
} 
suspect. Intervention may then be justified to alter existing preferences even without any showing of market failure. The illogic of this argument can best be demonstrated by an example. Consider a fully informed worker who chooses higher wages over job security. If the same worker had greater wealth, he might make the opposite choice. In this sense, the initial choice is determined by a given distribution of wealth. But it is extremely perverse to rely on this noncontroversial premise in order to justify denying the worker at a given level of wealth the right to make the trade-off in favor of higher wages by prohibiting contracts at will. Such a result denies the worker the ability to maximize his utility while leaving unaffected the existing distribution of wealth.

Even if wealth redistribution is still thought to be desirable in this context, it can be better accomplished through the tax system than through inefficient rules of law. ${ }^{30}$ Even proponents of current labor law who rely on distributional arguments should favor this approach. Among other advantages, it would have the effect of extending benefits to workers as a class rather than to the twenty percent of the workforce that is currently unionized.

30 The literature on this point is summarized in A. MitchemL Polinskr, AN InTroducTION TO LAW AND ECONOMICS 105-13 (1983). 